Ігор Вікторович Рубан (доктор технічних наук, професор) ${ }^{1}$

Вадим Володимирович Тютюник (доктор технічних наук, с.н.с.) $)^{2}$

Ольга Олександрівна Тютюник (кандидат технічних наук, доцент) ${ }^{3}$

${ }^{1}$ Харківський національний університет радіоелектроніки, Харків, Украӥна

${ }^{2}$ Національний університет циввільного захисту Украйни, Харків, Украйна

${ }^{3}$ Харківський національний економічний університет імені Семена Кузнеця, Харків, Украӥна

\title{
ОСОБЛИВОСТІ СТВОРЕННЯ СИСТЕМИ ПІДТРИМКИ ПРИЙНЯТТЯ АНТИКРИЗОВИХ РІШЕНЬ В УМОВАХ НЕВИЗНАЧЕНОСТІ ВХІДНОЇ ІНФОРМАЦІЇ ПРИ НАДЗВИЧАЙНИХ СИТУАЦІЯХ
}

\begin{abstract}
Запропоновано створення ефективної інформаційно-аналітичної підсистеми управління процесами попередження й локалізації наслідків надзвичайних ситуацій (НС) шляхом комплексного включення в діючу Єдину державну систему ичивільного захисту (ЄДСЦЗ) по вертикалі від об'єктового до державного рівнів різних функціональних елементів територіальної системи моніторингу НС та складових системи ситуаційних цеентрів. Показано, щуо однією з основних функцій системи ситуаційних центрів на всіх рівнях управління ЄДСЦЗ є розробка ефективних антикризових рішень, яка ускладнюється тим, що необхідними умовами ефективності рімень є їх своєчасність, повнота й оптимальність. Для підвищення ефективності прийняття рімень обгрунтовано необхідність розробки формальних, нормативних методів і моделей комплексного рішення проблеми прийняття рімень 6 умовах багатокритеріальності й невизначеності при управлінні процесами попередження й локалізації наслідків НС. 3 метою розвитку науково-технічних основ створення системи підтримки прийняття антикризових рімень в системі ситуаџійних центрів ЄДСЦЗ в роботі представлена методика обтрунтування оптимальних антикризових рішень щуодо забезпечення відповідного рівня безпеки життєдіяльності держави при НС різного характеру в умовах невизначеності вхідної інформації для експертів системи ситуаційних цеентрів.

Ключові слова: надзвичайна ситуація, Єдина державна система ицивільного захисту, система ситуаційних ичентрів, система підтримки прийняття антикризових рішень, багатокритеріальність, невизначеність вхідної інформації.
\end{abstract}

\section{Вступ}

Реалізація національних інтересів будь-якої країни в певний момент може зіткнутися із непередбачуваною кризовою ситуацією. Характер виникнення такої ситуації та можливі негативні наслідки у даному випадку вимагають негайного іiі вирішення силами колегіального органу, покликаного здійснити аналіз ситуації, запропонувати можливі шляхи виходу з кризового стану та надати прогнозне бачення щодо подальших перспектив. У багатьох країнах перелічені завдання покладаються на антикризові структури, зокрема ситуаційні центри, ситуаційнокризові центри, менше кризові центри. Значний спектр небезпек та ризиків, із якими стикаються практично всі сфери національної безпеки України (рис.1), та необхідність запобігання і нейтралізації негативним й деструктивним проявам, обумовлюють актуальність досліджень у зазначеному напрямку [1-3].

Цивільний захист, як одна із складових Системи національної безпеки України, спрямований на захист населення та територій від негативного впливу різного роду надзвичайних ситуацій (НС), яким притаманні ймовірнісний територіально-часовий розподіл виникнення джерел небезпек. Для забезпечення реалізації державної політики у сфері цивільного захисту функціонує Єдина державна система цивільного захисту (СДСЦЗ), яка складається 3 функціональних і територіальних підсистем $[4,5]$ та спрямована на розв'язання питань забезпечення необхідного рівня безпеки життєдіяльності території держави лише в умовах, коли виникла HC.

Згідно стратегії реформування Державної служби України з надзвичайних ситуацій (ДСНС) [6], серед актуальних напрямків удосконалення функціонування ЄДСЦЗ необхідно визначити низку проблемних питань науково-інформаційнотехнологічного характеру, які стосуються оптимального управління процесами попередження, локалізації та ліквідації наслідків НС. Одним 3 таких проблемних питань $\epsilon$ удосконалення механізму взаємодії ДСНС 3 іншими структурами усіх рівнів забезпечення національної безпеки шляхом подальшого розвитку державного центру управління в надзвичайних ситуаціях ДСНС, утворення відповідних регіональних центрів та налагодження 
ïх взаємодії з Головним ситуаційним центром та іншими ситуаційними центрами складових сектору безпеки і оборони.

Постановка проблеми. В Україні цілковито відкритими залишаються проблемні питання реалізації, базуючись на уявленнях системного підходу та за даними рис. 2, в системі ЄДСЦ3 функції моніторингу та розробки ефективних управлінських рішень всіх локальних підсистем, спрямованих на запобігання та локалізацію $\mathrm{HC}$, в умовах зародження джерел небезпек різної природи $[7,8]$.

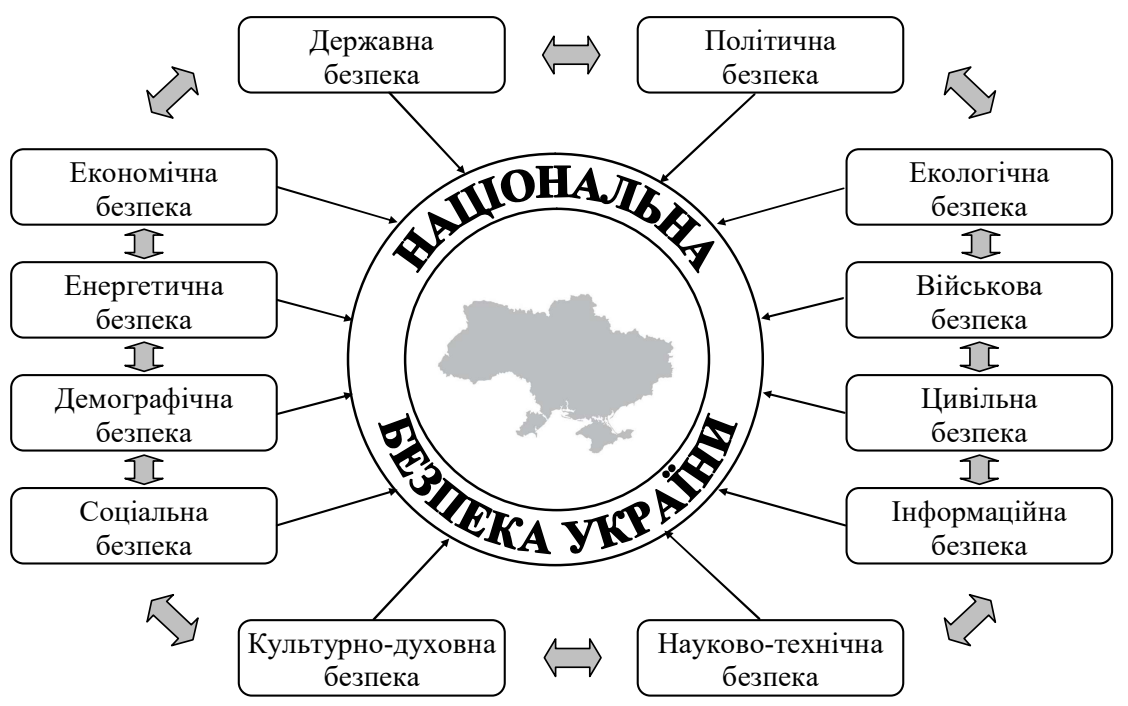

Рис. 1. Багатофакторна модель Системи національної безпеки України

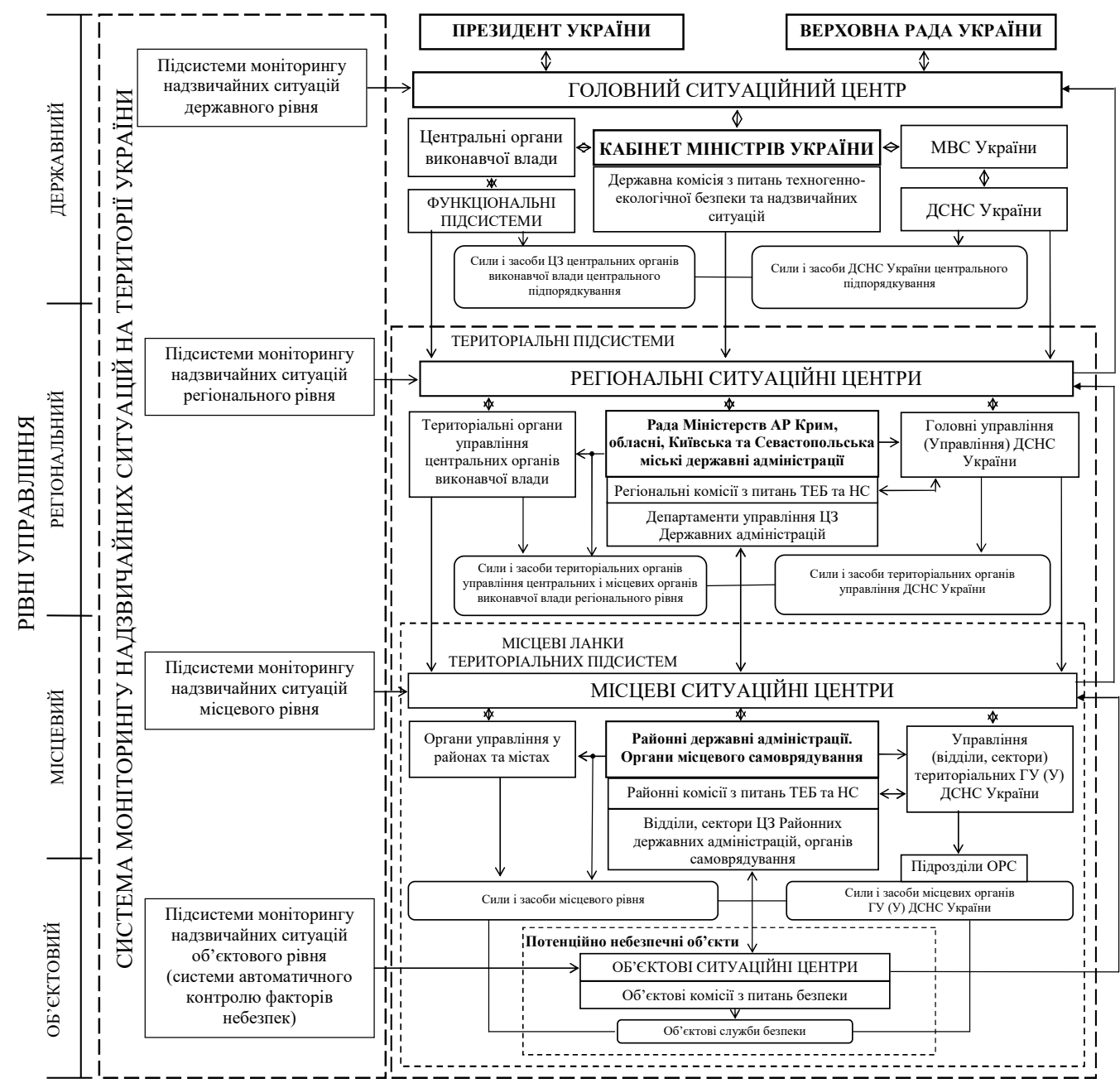

Рис. 2. Комплексна функціональна схема інформаційно-аналітичної підсистеми управління процесами запобігання, локалізації та ліквідації наслідків НС у Єдиній державній системі цивільного захисту 
Це вказує на необхідність термінового розв'язання питань включення до складу СДСЦЗ інформаційно-аналітичної підсистеми управління процесами запобігання та локалізації НС.

Створення ефективної інформаційноаналітичної підсистеми управління процесами запобігання та локалізації НС пропонується у відповідності за підходом, який розроблено у роботах $[9,10]$ та графічно представлено на рис. 2. У цьому підході реалізовано комплексне включення в діючу систему СДСЦЗ по вертикалі від об'єктового до державного рівнів різних функціональних елементів територіальної підсистеми моніторингу НC та складових підсистеми ситуаційних центрів, які жорстко пов'язані між собою на інформаційному та виконавчому рівнях для прийняття відповідних антикризових рішень для розв'язання різних функціональних задач моніторингу, запобігання та локалізації НС природного, техногенного, соціального та воєнного характеру.

Одним 3 актуальних напрямків розробки у ЄДСЦ3 інформаційно-аналітичної підсистеми управління процесами запобігання, локалізації та ліквідації наслідків НC $€$ створення та забезпечення функціонування підсистем автоматизованого виявлення на локальній території джерел небезпек та телекомунікаційних мереж, а також центрів обробки даних, 3 функціями інформаційної підтримки прийняття антикризових рішень в умовах невизначеності вхідної інформації при НС різного характеру.

Таким чином, обов'язковим етапом функціонування системи ситуаційних центрів $€$ прийняття рішень. При цьому не тільки невірні, але й неефективні рішення призводять до соціальних, матеріальних та екологічних збитків, або призводять до нераціонального використання фінансових, часових, трудових, енергетичних та інших ресурсів при управлінні процесами запобігання та ліквідації НС різного характеру. У зв'язку 3 цим проблема розробки науковообгрунтованої методології прийняття ефективних антикризових рішень $\epsilon$ однією 3 актуальних наукових проблем в галузі інформаційних технологій у сфері безпеки та оборони.

Аналіз останніх досліджень і публікацій. За визначенням В.М. Глушкова необхідними умовами ефективності рішень є їх своєчасність, повнота і оптимальність [11]. Перераховані вимоги суперечливі i їх забезпечення пов'язане 3 серйозними труднощами.

Забезпечення повноти (комплексності) рішень вимагає якомога повнішого врахування внутрішніх і зовнішніх факторів, що впливають на прийняття рішення, глибокого аналізу їх взаємозв'язків, що веде до зростання розмірності задачі прийняття рішень, іiі багатокритеріальності. У свою чергу це призводить до зростання невизначеності вихідних даних, що обумовлено неповнотою знань про взаємозв'язок факторів i, як наслідок, неточного ii опису, неможливістю або неточністю вимірювання деяких факторів, випадкових зовнішніх і внутрішніх впливів тощо. Додаткова складність полягає в тому, що невизначеності різнорідні і можуть бути представлені у вигляді випадкових величин, нечітких множин або просто інтервальних величин.

Таким чином, підвищення ефективності прийнятих рішень пов'язано 3 необхідністю вирішення задач багатокритеріальної оптимізації в умовах невизначеності.

Традиційний, широко розповсюджений підхід до вирішення таких завдань, заснований на їх евристичному спрощенню (детермінізації) як засобу зменшення невизначеності, в міру ускладнення завдань і підвищення значущості рішень стає все менш ефективним.

У цих умовах вкрай актуальна розробка формальних (нормативних) методів i моделей комплексного вирішення проблеми прийняття рішень в умовах багатокритеріальності і невизначеності.

У цьому напрямі ведуться інтенсивні дослідження зарубіжними i вітчизняними вченими, такими як Фішберн П. [12], Сааті Т. [13], Райфа Р. [14], Кіні Р. [14], Заде Л. [15], Подіновський В.В. [16], Зайченко Ю.П. [17], Волошин А.Ф. [18], Ларічев А.І. [19], Борисов А.Н. [20], Вощинін А.П. [21], Кофман А. [22], Орловський С.А. [23], Поспєлов Д.А. [24], Ротштейн О.П. [25], Петров Е.Г. [26-27] та багато інших. Були отримані фундаментальні результати, однак вичерпне рішення проблеми далеко від завершення і продовження досліджень в цьому напрямку, безсумнівно, актуально як в теоретичному, так і в прикладному аспектах для розробки методики обгрунтування, в умовах невизначеності вхідної інформації для експертів системи ситуаційних центрів, оптимальних антикризових рішень щодо забезпечення необхідного рівня життєдіяльності держави при НC природного, техногенного, соціального i військового характеру.

Метою статті $\epsilon$ розвиток науково-технічних основ створення системи підтримки прийняття антикризових рішень експертами системи ситуаційних центрів Єдиної державної системи цивільного захисту в умовах невизначеності вхідної інформації при НС природного, техногенного, соціального і військового характеру.

\section{Виклад основного матеріалу дослідження}

Мета роботи досягається шляхом розробки методики обгрунтування оптимальних антикризових рішень щодо забезпечення відповідного рівня безпеки життєдіяльності держави при НС різного характеру, в умовах невизначеності вхідної інформації для експертів системи ситуаційних центрів.

Ситуаційний центр при функціонуванні в ЄДСЦЗ повинен, у відповідності до даних рис. 3, забезпечити: 1) аналіз отриманої від підсистеми моніторингу інформації; 2) моделювання розвитку НС на території міста, регіону, держави; 
3) розробку та ухвалення управлінських рішень щодо попередження та ліквідації $\mathrm{HC}$, а також мінімізації їх наслідків.

Функціонування, представленої на рис. 3, схеми в умовах повноти вхідної інформації та наявності одного часткового критерію оцінювання множини допустимих рішень не представляє труднощів при обгрунтування оптимальних антикризових рішень. 3 іншого боку, сучасні проблемні ситуації характеризуються неповнотою знань (невизначеністю) вихідних даних та множиною часткових критеріїв оцінювання. Таким чином, традиційний підхід, заснований на декомпозиції проблеми на дві умовно незалежні задачі - багатокритеріальної оптимізації в детермінованій, тобто без урахування невизначеності, постановці і прийняття рішення в умовах невизначеності для скалярної цільової функції в сучасних умовах, не задовольняє вимогам практики за точністю й ефективністю.

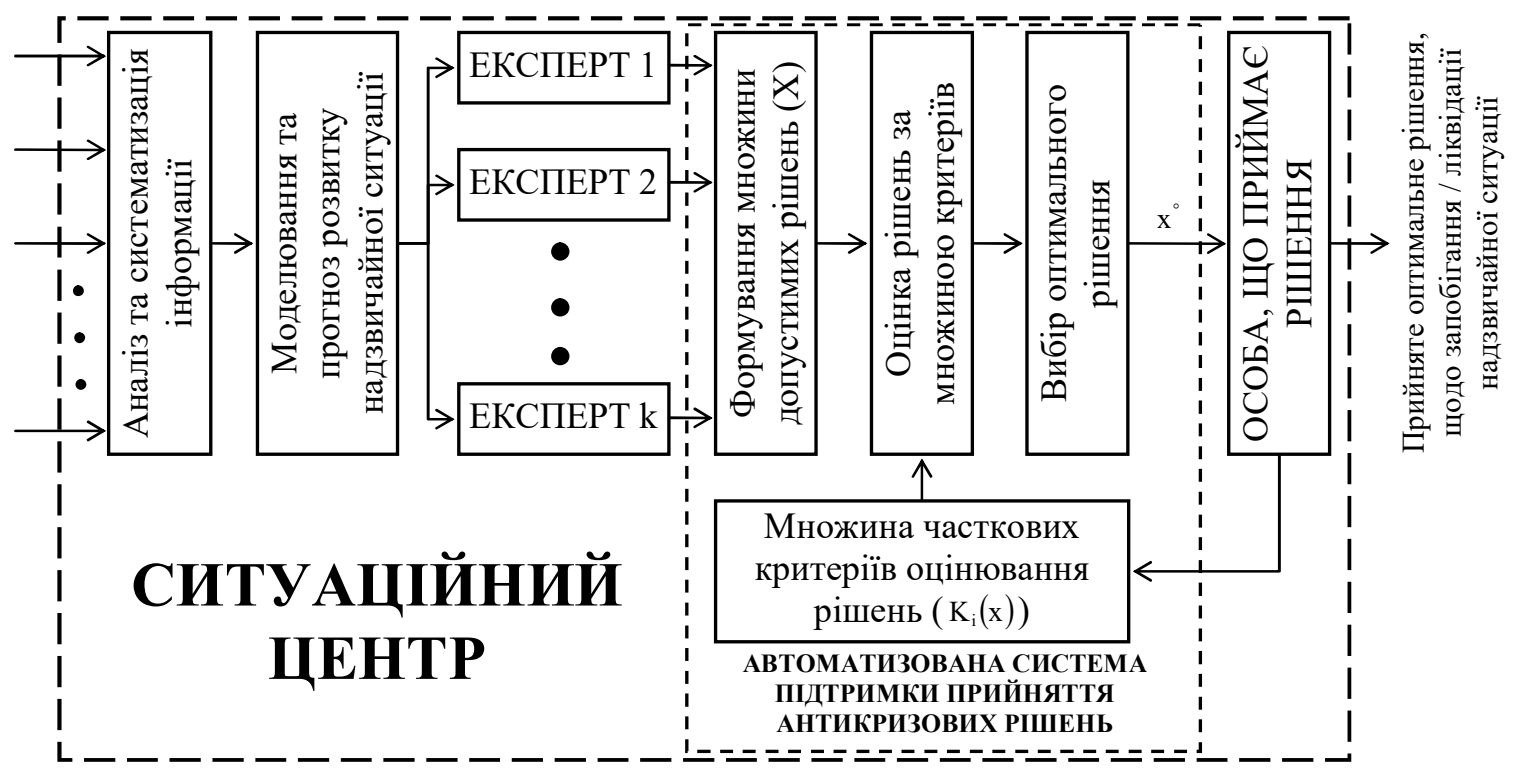

Рис. 3. Функціональна схема обгрунтування оптимальних антикризових рішень щодо забезпечення відповідного рівня безпеки життєдіяльності держави при надзвичайних ситуацій різного характеру, в умовах невизначеності вхідної інформації для експертів системи ситуаційних центрів

Єдиної державної системи цивільного захисту

Це обумовлено тим, що задача багатокритеріальної оптимізації в принципі $\epsilon$ некоректною, тому що дозволяє визначити рішення тільки 3 точністю до області компромісних рішень, а іï регуляризація для визначення єдиного рішення, заснована на розрахунку узагальненої багатофакторної скалярної оцінки, базується на погано структурованих, суб'єктивних експертних оцінках, детермінізація яких призводить до великих похибок. 3 іншого боку, методи прийняття рішень в умовах невизначеності за скалярною оцінкою і очікуваного ефекту, без урахування його багатокритеріальності, так само не адекватні. Тому викає необхідність розвитку методології комплексного вирішення задачі прийняття рішень 3 урахуванням багатокритеріальності і неповної невизначеності вихідних даних.

Допустима множина рішень експертів ситуаційного центру Єдиної державної системи цивільного захисту у загальному випадку, згідно [28], включає підмножину узгоджених $\mathrm{X}^{\mathrm{S}}$ та неузгоджених (компромісних) $\mathrm{X}^{\mathrm{C}}$ рішень щодо забезпечення відповідного рівня безпеки на відповідному рівні життєдіяльності (об'єктовому, місцевому, регіональному та державному) при НС.
Особливістю останньої підмножини $\epsilon$ неможливість покращити ні одного часткового критерію $\mathrm{k}_{\mathrm{i}}(\mathrm{x}), \mathrm{i}=\overline{1, \mathrm{n}}$ без погіршення якості хоч би одного іншого часткового критерію. Крім того, ефективне рішення $\mathrm{x}^{\circ}$ обов'язково належить області компромісів. Це означає, що задача багатокритеріальної оптимізації не має рішення, тобто є некоректною задачею згідно Адамару [29], оскільки у загальному випадку не забезпечує визначення єдиного оптимального рішення із множини компромісів $X^{C}$

$$
x^{\circ}=\arg \underset{x \in X}{\operatorname{extr}}<k_{i}(x)>, \forall i=\overline{1, n} .
$$

У зв'язку з цим, викає задача багатокритеріальної оптимізації. Основна ідея методів розв'язання багатокритеріальної задачі прийняття рішення базується на розробці деякої регуляризируючої процедури, яка дозволяє вибрати єдине рішення із області компромісів $X^{C}$. Для цього можливі два підходи, а саме:

1) евристичний, коли вибір рішення здійснює особа, що приймає рішення, на основі свого опиту;

2) формальний, оснований на деяких формальних правилах (схемах компромісу).

Основними методами регуляризації задачі 
багатокритеріальної оптимізації $€$ принцип головного критерію, функціонально-вартісний аналіз та принцип послідовної оптимізації. Кожен 3 перерахованих підходів має свою область коректного використання, але найбільш загальним i універсальним є підхід, який базується формуванні множини часткових критеріїв $K_{i}(x)=K_{\phi}(x) \cup K_{3}(x)=\left\{k_{i}(x)\right\}, \quad i=\overline{1, n}$ узагальненої скалярної оцінки (критерію), яку називають функцією корисності та можливо представити у вигляді

$$
\bar{K}(x) \equiv P(x)=F\left[\lambda_{i}, K_{i}(x)\right], i=\overline{1, m},
$$

де $\lambda_{i}-$ коефіцієнти ізоморфізму, які приводять різнорідні часткові критерії $K_{i}(x)$ до ізоморфного вигляду;

$$
\begin{aligned}
& K_{\phi}(x) \text { - функціональний критерій; } \\
& K_{3}(x) \text { - затратний критерій. }
\end{aligned}
$$

Теоретичною основою формування багатокритеріальних скалярних оцінок $є$ теорія корисності [30], яка базується на існуванні кількісної оцінки щодо переваги рішень. Це означає, що

$$
x_{1}, x_{2} \in X, x_{1} \succ x_{2} \text {, то } P\left(x_{1}\right)>P\left(x_{2}\right),
$$

де $P\left(x_{1}\right), P\left(x_{2}\right)$ - функції корисності.

У загальному випадку справедливо і зворотне твердження. Так, корисність є кількісною мірою “якості" прийнятого рішення, а саме

$$
x^{\circ}=\underset{x \in X}{\arg \max } P(x) .
$$

У зв'язку з цим виникає задача обгрунтування правила (метрики), який дозволить сформувати функцію корисності у просторі часткових критеріїв $k_{i}(x)$.

Принциповим є те, що об'єктивної метрики не існує, а принцип ранжирування рішень щодо запобігання та ліквідації НC відображає суб'єктивні переваги конкретної особи ситуаційного центру, що приймає рішення.

Розглянемо системологічні основи вибору метрики функції корисності щодо запобігання та ліквідації НС. Синтез любої математичної моделі, у тому числі і синтез функції корисності, передбачає необхідність вирішення двох взаємопов'язаних задач: структурної та параметричної ідентифікації. Перша задача передбачає: визначення значущих факторів, що впливають на вихідні дані моделі; визначення структури, тобто виду оператора, який встановлює зв'язок між вхідними та вихідними даними моделі. Розв'язання задачі параметричної ідентифікації полягає у визначенні конкретних кількісних значень параметрів моделі.

Задача структурної ідентифікації моделі пов'язана 3 евристичним висуненням і перевіркою деякої гіпотези. У випадку функціонування ситуаційного центру вигляд функції корисності рішення $\mathrm{x}$ визначається частковими характеристиками (критеріями) $k_{i}(x)$. Наступним етапом розв'язання задачі є ідентифікація виду оператора $F$. Найбільш широко відомі дві форми функції корисності, а саме: адитивна та мультиплікативна.

Адитивна функція корисності. Великий внесок в обгрунтування цієї гіпотези зроблено Фишберном [12]. Їм були визначені необхідні та достатні умови адекватності адитивної функції корисності для багатьох випадків. Так, у випадку n факторів, умови адитивності функції корисності за Фишберном можна сформулювати наступним чином: фактори $x_{1}, x_{2}, \ldots x_{n} \in$ адитивно незалежними, якщо перевага лотерей на $x_{1}, x_{2}, \ldots x_{n}$ залежить тільки від маргінальних розподілів ймовірностей. Використовуючи це визначення можна сформулювати основний результат теорії адитивної корисності як:

$$
P(x)=\sum_{i=1}^{n} \lambda_{i} k_{i}(x) .
$$

Мультиплікативна форма функції корисності має наступний вигляд:

$$
P(x)=\prod_{i=1}^{n} \lambda_{i} k_{i}(x) .
$$

Аналіз показав що, мультиплікативна форма не дозволяе врахувати інформацію про вагові коефіцієнти. Недоліком адитивної форми $є$ те, що вона не дозволяє враховувати нелінійність і взаємозв'язок окремих критеріїв. Тому в загальному випадку необхідна більш універсальна структура функції корисності, яка дозволила б враховувати як адитивну форму так і нелінійні ефекти.

В якості такої універсальної форми може бути використано поліном Колмогорова-Габора [31], який в загальному випадку має вигляд:

$$
\begin{aligned}
P(Y) & =\lambda_{0}+\sum_{i=1}^{n} \lambda_{i} x_{i}+\sum_{i=1}^{n} \sum_{i \leq j} \lambda_{i j} x_{i} x_{j}+ \\
& +\sum_{i=1}^{n} \sum_{j \leq i} \sum_{k \leq j} \lambda_{i j k} x_{i} x_{j} x_{k}+\ldots
\end{aligned}
$$

Для оцінки корисності цей поліном необхідно модифікувати, шляхом визначення $\lambda_{0}=0$. В результаті поліном прийме вигляд:

$$
P(Y)=\sum_{i=1}^{n} \lambda_{i} k_{i}+\sum_{i=1}^{n} \sum_{j=1}^{n} \lambda_{i j} k_{i} k_{j}+\ldots .
$$

При цьому, у більшості практичних ситуацій (у тому числі при функціонуванні ситуаційних центрів в питаннях прийняття антикризових рішень щодо запобігання та ліквідації $\mathrm{HC}$ ) достатньо враховувати члени не вище другого порядку.

Поліном Колмогорова-Габора містить фрагменти адитивної і мультиплікативної функції, а також є лінійним за параметрами. 3 огляду на це шляхом розширення простору змінних за рахунок введення додаткових змінних типу $\sum_{i=1}^{n} \sum_{j=1}^{n} k_{i} k_{j}=z_{l}$ 
тощо, отримаємо адитивну функцію наступного вигляду:

$$
P(x)=\sum_{l=1}^{L} \lambda_{l} z_{l}, .
$$

Виходячи 3 вищевикладеного розглянемо адитивну форму більш докладно, для наочності скориставшись моделлю (5). Всі часткові критерії, за визначенням, мають різну розмірність, інтервали і шкали вимірювання [32], тобто їх неможливо порівняти між собою.

Отже, вираз (4) справедливий тільки в тому випадку, якщо $\lambda_{i}$ враховують важливість часткових критеріїв, а також $€$ коефіцієнтами ізоморфізму, тобто приводять різнорідні $k_{i}(x)$ до єдиної розмірності та інтервалу вимірювання. Однак, у загальному випадку, важко визначити значення цих коефіцієнтів ізоморфізму. Цю обставину можна подолати, якщо представити адитивну функцію корисності в наступній формі:

$$
P(x)=\sum_{i=1}^{n} a_{i} k_{i}^{H}(x)
$$

де $\mathrm{a}_{\mathrm{i}}$ - відносні безрозмірні вагові коефіцієнти, для яких виконуються обмеження

$$
0 \leq a_{i} \leq 1, \quad \sum_{i=1}^{n} a_{i}=1,
$$

a $k_{i}^{H}(x)$ - нормалізовані, тобто приведені до ізоморфного вигляду часткові критерії [33]. Нормалізація критеріїв проводиться за виразом

$$
k_{i}^{H}(x)=\left(\frac{k_{i}(x)-k_{i}^{H \Gamma}}{k_{i}^{H K}-k_{i}^{H \Gamma}}\right)^{\alpha_{u}},
$$

де $k_{i}(x)$ - значення часткового критерію, $k_{i}^{H K}$, $k_{i}^{H \Gamma}$ - відповідно найкраще і найгірше значення часткового критерію, яке він приймає на області допустимих рішень $x \in X$.

Залежно від виду екстремуму (напрямки домінування)

$$
\begin{gathered}
k_{i}^{H K}=\left\{\begin{array}{l}
\max _{x \in X} k_{i}(x), \text { if } k_{i}(x) \rightarrow \max \\
\min _{x \in X} k_{i}(x), \text { if } k_{i}(x) \rightarrow \min
\end{array},\right. \\
k_{i}^{H \Gamma}=\left\{\begin{array}{l}
\min _{x \in X} k_{i}(x), \text { if } k_{i}(x) \rightarrow \max \\
\max _{x \in X} k_{i}(x), \text { if } k_{i}(x) \rightarrow \min
\end{array} .\right.
\end{gathered}
$$

Модель (10) конструктивна лише у тому випадку, коли вагові коефіцієнти $\mathrm{a}_{\mathrm{i}}$ часткових критеріїв задано у вигляді точкових кількісних значень [34]. Як визначалося вище, носіями цієї інформації $€$ особи, що приймають рішення, а значить, виникає необхідність розробки процедури ii отримання, тобто розв'язання задачі параметричної ідентифікації моделі. 3 різних причин отримання точної кількісної інформації про значення $\mathrm{a}_{\mathrm{i}}$ не завжди можливо, тому, в загальному випадку, оцінювання корисності рішень доводиться проводити в умовах існування більшою чи меншою міри невизначеності про взаємну важливість часткових критеріїв. В загальному випадку, загальна модель визначення корисності рішення $x \in X$ має вигляд

$$
\mathrm{P}(\mathrm{x})=\mathrm{G}\left[\mathrm{J}\left(\mathrm{a}_{\mathrm{i}}\right), \mathrm{k}_{\mathrm{i}}(\mathrm{x})\right], \quad \mathrm{i}=\overline{1, \mathrm{n}},
$$

де $J\left(a_{i}\right)$ - інформація про значеннях коефіцієнтів відносної важливості.

Крайніми ситуаціями є випадки, коли:

1) вагові коефіцієнти $a_{i}$ завдано у вигляді точних точкових кількісних значень;

2) інформація про перевагу часткових критеріїв повністю відсутня.

Як правило, між цими крайнощами є безліч ситуацій 3 різним ступенем невизначеності завдання вагових коефіцієнтів. Виходячи 3 представленого підходу, в роботі вирішена задача синтезу моделі обчислення інтервального фазифікованого значення скалярної багатофакторної оцінки ефективності (корисності) припустимих рішень.

Передбачається, що модель обчислення функції корисності в загальному випадку являє собою деякий фрагмент поліному Колмогорова-Габора, лінійний за параметрами, але нелінійний за змінними (частковим критеріям). Це означає, що в розширеному просторі змінних модель функції корисності $\mathrm{P}(\mathrm{x})$ можна розглядати як адитивну функцію виду

$$
\bar{P}(x)=\sum_{i=1}^{n} \overline{a_{i}} \overline{k_{i}^{H}}(x),
$$

де $\overline{a_{i}}-$ безрозмірні вагові коефіцієнти, що задовольняють вимогам $0 \leq a_{i} \leq 1, \sum_{i=1}^{n} a_{i}=1 ; \overline{k_{i}^{H}}(x)$ нормалізовані, тобто приведені до безрозмірного виду, однакової метрики і напряму домінування, часткові критерії; знак «-» означає інтервальну невизначеність.

Аналіз особливостей задачі багатокритеріального скалярного оцінювання, проведений у $[34,35]$, показав, що поширеною формою подання невизначеностей у моделі (16) $є$ нечіткі множини. При прийнятих допущеннях параметрична ідентифікація моделі задачі багатокритеріальної оптимізації (16) полягає у визначенні інтервальних значень параметрів $\overline{a_{i}}$ i часткових критеріїв $\overline{k_{i}}(x)$, їх фазифікації й обчисленні інтервального фазифікованого значення функції корисності рішення $P(x)$.

Оскільки задача багатофакторного оцінювання при функціонуванні ситуаційного центру в умовах HC $\epsilon$ інтелектуальною процедурою i носіями вихідної інформації $\epsilon$ експерти, задача параметричної ідентифікації параметрів моделі (16) вирішується безпосередньо методами 
експертного оцінювання або методом компараторної ідентифікації.

Метод компараторної ідентифікації адитивної моделі скалярного оцінювання корисності альтернатив полягає в такому. Вихідною інформацією виступає відношення строгого або нестрогого порядку, встановлене експертами на множині припустимих альтернатив

$$
x_{1} \succ x_{2} \sim x_{3} \sim x_{4} \succ \ldots,
$$

де $\succ, \sim-$ відповідно знаки переваги та еквівалентності. Відповідно до теорії корисності для (17) виконуються такі співвідношення

$$
P\left(x_{1}\right)>P\left(x_{2}\right)=P\left(x_{3}\right)>P\left(x_{4}\right)>\ldots
$$

На основі (18) можна скласти систему рівнянь виду

$$
\begin{aligned}
& P\left(x_{2}\right)-P\left(x_{1}\right) \leq 0, \\
& P\left(x_{3}\right)-P\left(x_{2}\right)=0, \\
& P\left(x_{4}\right)-P\left(x_{3}\right) \leq 0 .
\end{aligned}
$$

Підстановкою в (19) функції корисності (16) отримаємо систему лінійних щодо параметрів $\mathrm{a}_{\mathrm{i}}$ нерівностей, що визначають область їх можливих значень. Методом лінійного програмування на виділеній області визначаються інтервальні значення $\left[a_{i}^{\max }, a_{i}^{\text {min }}\right]$ параметрів. При цьому, незалежно від методу, визначаються інтервальні оцінки параметрів $a_{i}=\left[a_{i}^{\text {max }}, a_{i}^{\text {min }}\right] ; \forall i=\overline{1, n}$, а величина інтервалів залежить від розкиду суб'єктивних індивідуальних оцінок експертів.

Інтервальна невизначеність змінних моделі (часткових критеріїв) визначається Не-факторами. Їх аналіз та урахування дозволяє визначити інтервал можливих значень кожного з них.

Наступний етап ідентифікації моделі (16) полягає в іiі фазифікації, тобто у виборі виду i параметрів функції належності інтервальних параметрів і змінних.

Вагові коефіцієнти $\mathrm{a}_{\mathrm{i}}$ являють собою інтервальні нечіткі числа, а значення часткових критеріїв можуть бути задані як чисельно, у вигляді нечітких чисел, так і якісно, у вигляді лінгвістичних термів.

Таким чином, наведені результати свідчать, що створення в Україні ситуаційних центрів, як елементів ЄДСЦЗ, відбувається в умовах імовірнісного територіально-часового розподілу джерел виникнення небезпек. Це обумовлюється невизначеністю параметрів, які впливають на умови нормального функціонування території України. У зв'язку 3 цим виникає проблема прийняття оптимальних антикризових рішень в умовах невизначеності щодо забезпечення відповідного рівня безпеки життєдіяльності держави.

Показано, що процедура прийняття експертами ситуаційного центру управлінських антикризових рішень ускладнюється тим, що необхідними умовами ефективності рішень є їх своєчасність, повнота й оптимальність. Тому, підвищення ефективності прийнятих рішень пов'язане 3 необхідністю рішення задачі багатокритеріальної оптимізації в умовах невизначеності. Це потребує розробки формальних, нормативних методів і моделей (наукові основи яких представлені у роботі) для комплексного рішення проблеми прийняття рішень в умовах багатокритеріальності й невизначеності при управлінні процесами запобігання та локалізації НС для забезпечення ефективного функціонування СДСЦЗ за трьома групами критеріїв, а саме: показники забезпечення відповідного рівня безпеки життєдіяльності; показники функціональної спроможності ЄДСЦЗ; показники фінансових затрат на функціонування цієї системи безпеки.

\section{Висновки й перспективи подальших досліджень}

Викладені основні принципи створення підсистеми підтримки прийняття антикризових рішень в умовах невизначеності вхідної інформації системи ситуаційних центрів СДСЦЗ:

1. Запропоновано створення ефективної інформаційно-аналітичної підсистеми управління процесами запобігання та ліквідації НС шляхом комплексного включення в діючу систему СДСЦЗ по вертикалі, від об'єктового до державного рівнів різних функціональних елементів територіальної системи моніторингу НС та складових системи ситуаційних центрів, які жорстко пов'язані між собою на інформаційному та виконавчому рівнях для прийняття відповідних антикризових рішень, для розв'язання різних функціональних задач моніторингу, запобігання та ліквідації НС природного, техногенного, соціального та воєнного характеру.

2. Показано, що основу ситуаційного центру становить підсистема підтримки прийняття антикризових рішень, яка забезпечує експертну оцінку обстановки на об'єкті управління та розвитку загроз на території міста, регіону, держави, а також розробку та ухвалення управлінських рішень щодо запобігання та ліквідації НC, а також мінімізації їх наслідків. Обов'язковою умовою функціонування підсистеми підтримки прийняття антикризових рішень $є$ те, що не тільки невірні, але й неефективні рішення призводять до соціальних, матеріальних та екологічних збитків, або призводять до нераціонального використання фінансових, часових, трудових, енергетичних та інших ресурсів при управлінні процесами запобігання та ліквідації НС різного характеру.

3. Встановлено, що створення в Україні ситуаційних центрів, як елементів СДСЦЗ, відбувається в умовах імовірнісного територіально-часового розподілу джерел виникнення небезпек. Це обумовлюється невизначеністю параметрів, які впливають на умови нормального функціонування території України. У зв'язку 3 цим виникає проблема 
прийняття оптимальних антикризових рішень в умовах невизначеності щодо забезпечення відповідного рівня безпеки життєдіяльності держави.

4. Показано, що процедура прийняття експертами ситуаційного центру управлінських антикризових рішень ускладнюється тим, що необхідними умовами ефективності рішень $\epsilon$ їх своєчасність, повнота й оптимальність. Тому, підвищення ефективності прийнятих рішень пов'язане 3 необхідністю рішення задачі багатокритеріальної оптимізації в умовах невизначеності. Це потребує розробки

\section{Jimepamypa}

1. Про національну безпеку України: Закон України від 21 червня 2018 року № 2469-VIII [Електронний ресурс]. Режим доступу: http://zakon.rada.gov.ua/laws/show/246919 2.Чеховська М.М. Міжнародний досвід створення ситуаційних центрів у процесі безпекового супроводу реалізації національних інтересів. [Електронний ресурс]. Режим доступу: http://pap.in.ua/4_2014/62.pdf 3 . Вишневский В.В., Симонов С. В. Организационные процедуры ситуационного центра Математичні машини $i$ системи. 2010. № 4. С. 62-67. 4. Черногор Л.Ф. Физика и экология катастроф. Харьков: Харьковский национальный университет имени В.Н. Каразина, 2012. 556 с. 5. Тютюник В.В., Черногор Л.Ф., Калугін В.Д. Системний підхід до оцінки небезпеки життєдіяльності при територіально часовому розподілі енергії джерел надзвичайних ситуацій. Проблеми надзвичайних ситуаџій. 2011. Вип. 14. С. 171 - 194. 6. Розпорядження Кабінету Міністрів України від 25 січня 2017 року № 61-р. «Про схвалення Стратегії реформування системи Державної служби України 3 надзвичайних ситуацій» [Електронний pecypc]. Режим доступу: http://zakon5.rada.gov.ua/laws/show/61-2017-\%D1\%80

7. Калугін В.Д., Тютюник В.В., Торногор Л.Ф., Шевченко P.I. Системний підхід до оцінки ризиків надзвичайних ситуацій в Україні. ВосточноЕвропейский журнал передовых технологий. 2012. 1/6 (55). С. 59-70. 8. Тютюник В.В., Соболь О.М., Калугін В.Д., Тютюник Ю.В. Основи методології територіально-часового формування джерел надзвичайних ситуацій та екологічної небезпеки на локальній території. Техногенно-екологічна безпека та ичивільний захист. Київ: Інститут геохімії навколишнього середовища НАН України. 2015. Вип. 9. С. 92 - 108 9. Тютюник В.В. Створення комплексної системи моніторингу надзвичайних ситуацій в регіонах України. Автореф. ... доктора технічних наук за спец. 21.02.03 - Цивільний захист. Київ: НАН України. ДП «нститут геохімії навколишнього середовища НАН України», 2015. 42 с. 10. Тютюник В.В., Стрілець В.М., Калугін В.Д., Захарченко Ю.В. Розвиток методологічного підходу для техногенноекологічної оцінки рівня небезпеки функціонування структурних підрозділів потенційно небезпечних об'єктів та локальних територій України. Науково-технічний журнал «ТЕХНОГЕННО-ЕКОЛОГІЧНА БЕЗПЕКА». № 3(1/2018). С.91 - 101.11. Глушков В.М. Введение в теорию самосовершенствующихся систем. Киев: Изд-во КВИРТУ. 109 с. 12. Фишберн П. Теория полезности для принятия решений. М.: Наука, 1978. 352c. 13. Саати Т. Математические модели конфликтных ситуаций. М.: Сов. Радио, 1977. 304 с. 14. Кини Р.Л., Райфа Х. Принятие решений при многих критериях: предпочтения и замещения. М.: «Радио и связь», 1981. 560 с. 15. Заде Л. Понятие лингвистической переменной и его применение к принятию приближенных решений формальних, нормативних методів і моделей (наукові основи яких представлені у роботі) для комплексного рішення проблеми прийняття рішень в умовах багатокритеріальності й невизначеності при управлінні процесами запобігання та локалізації НС для забезпечення ефективного функціонування СДСЦЗ за трьома групами критеріїв, а саме: показники забезпечення відповідного рівня безпеки життєдіяльності; показники функціональної спроможності ЄДСЦЗ; показники фінансових затрат на функціонування цієї системи безпеки.

М.: «Мир», 1976. 16. Подиновский В.В., Ногин В.Д. Парето-оптимальные решения многокритериальных задач. М.: Наука, 1982. 254 с. 17. Зайченко Ю.П. Дослідження операцій. 7-ме вид. К.: Видавничий Дім «Слово», 2006. 816 с. 18. Волошин О.Ф., Мащенко С.О. Теорія прийняття рішень: Навчальний посібник. К.: Видавничо-поліграфічний центр «Київський університет», 2006. 304 с. 19. Ларичев О.И., Мошкович E.M. Количественные методы принятия решений. М.: Наука, Физматлит, 1996. 208 с. 20. Борисов А.Н., Крумберг О.А., Федоров И.П. Принятие решений на основе нечетких моделей: Примеры использования. Рига: Зинатне, 1990. 184 с. 21. Вощинин А.П., Сотиров Г.Р. Оптимизация в условиях неопределенности. Изд-во МЭИ и Техника, 1989. 224c. 22. Кофман А. Введение в теорию нечетких множеств. М., Радио и связь, 1982. 23. Орловский С.А. Проблемы принятия решений при нечеткой информации. М.:Наука, 1981. 206 с. 24. Поспелов Д.А. Логико-лингвистические модели в системах управления. М.: Энергоиздат, 1981. 232 с 25. Ротштейн А. П. Интеллектуальные технологии идентификации: нечеткая логика, генетические алгоритмы, нейронные сети. Винница: УНИВЕРСУМ - Винница, 1999. 320 с. 26. Петров Э.Г., Писклакова О.А. Анализ подходов к решению задачи поиска оптимального решения в условиях неопределенности. Вестник ХНТУ. 2007. №4(27). С. 14-19. 27. Петров Э.Г., Писклакова О.А. Постановка задачи взаимной трансформации различных видов неопределенности. Комп'ютерне моделювання та інтелектуальні системи: Збірник наукових праць. 2007. С.190 - 193. 28. Петров Е.Г., Новожилова М.В., Гребеннік І.В. Методи і засоби прийняття рішень в соціально - економічних системах. К.: Техніка, 2004. 256 с. 29. Прохоров Ю.В. Математический энциклопедический словарь. М.: Сов. энциклопедия, 1988. 250 с. 30. Нейман Дж., Моргенштерн О. Теория игр и экономическое поведение. М.: Наука, 1970. 124 с. 31. Ивахненко А.Г, Мюллер Й.А. Самоорганизация прогнозирующих моделей. К.:Техніка, 1985. 223 с. 32. Клигер С.А., Косолапов М.С., Толстова Ю.Н. Шкалирование при сборе и анализе социологической информации. М.: Наука, 1978. 168 с. 33. Катулев А.Н., Виленчук Л.С., Михно В.Н. Современный синтез критериев в задачах принятия решений. М.: Радио и связь, 1992. 119 с. 34. Петров Э.Г., Шило Н.С. Методика оценки адекватности моделей точечной идентификации индивидуальных предпочтений ЛПР. Радиоэлектроника и информатика. 2003. №2. С. 97-103. 35. Ruban Igor, Tiutiunyk Vadym, Tiutiunyk Olha. Features of decision support by experts of the situational center under conditions of uncertainty of input information in emergency situations. Інформаційні технології i безпека. Матеріали XX Міжнародної науково-практичної конференції ІТБ-2020. C. $120-124$ 


\title{
ОСОБЕННОСТИ СОЗДАНИЯ СИСТЕМЫ ПОДДЕРЖКИ ПРИНЯТИЯ АНТИКРИЗИСНЫХ РЕШЕНИЙ В УСЛОВИЯХ НЕОПРЕДЕЛЕННОСТИ ВХОДНОЙ ИНФОРМАЦИИ ПРИ ЧРЕЗВЫЧАЙНЫХ СИТУАЦИЯХ
}

\author{
Игорь Викторович Рубан (доктор технических наук, профессор) $)^{1}$ \\ Вадим Владимирович Тютюник (доктор технических наук, с.н.с.) ${ }^{2}$ \\ Ольга Александровна Тютюник (кандидат технических наук, доцент) ${ }^{3}$
}

\begin{abstract}
${ }^{1}$ Харьковский национальный университет радиоэлектроники, Харьков, Украина
${ }^{2}$ Национальный университет гражданской защиты Украины, Харьков, Украина

${ }^{3}$ Харковский национальный экономический университет имени Семена Кузнеца, Харьков, Украина
\end{abstract}

Предложено создание эффективной информационно-аналитической подсистемы управления процессами предупреждения и локализаџии последствий чрезвычайных ситуаций (ЧС) путем комплексного включения в действующую Единую государственную систему гражданской защить (ЕГСГЗ) по вертикали от объектового до государственного уровней различных функциональных элементов территориальной системы мониторинга ЧС и составляющих системы ситуационных центров. Показано, что одной из основных функций системы ситуационных центров на всех уровнях управления ЕГСГЗ является разработка эффективных антикризисных решений, которая осложняется тем, что необходимыми условиями эффективности решений является их своевременность, полнота и оптимальность. Для повышения эффективности принятия решений обоснована необходимость разработки формальных, нормативных методов и моделей комплексного решения проблемы принятия решений в условиях многокритериальности и неопределенности при управлении процессами предупреждения и локализации последствий ЧС. С целью развития научно-технических основ создания системы поддержки принятия антикризисных решений в системе ситуационных иентров ЕДСЦЗ в работе представлена методика обоснования оптимальных антикризисных решений по обеспечению соответствующего уровня безопасности жизнедеятельности государства при ЧС различного характера в условиях неопределенности входной информаџии для экспертов системы ситуационных иентров.

Ключевые слова: чрезвычайная ситуация, Единая государственная система гражданской защиты, система ситуационных иентров, система поддержки принятия антикризисных решений, многокритериальность, неопределенность исходной информации.

\section{FEATURES OF CREATING ANTI-CRISIS DECISION SUPPORT SYSTEM UNDER UNCERTAINTY OF INPUT INFORMATION IN EMERGENCY SITUATIONS}

\author{
Igor Ruban (Doctor of Technical Sciences, Professor) ${ }^{1}$ \\ Vadym Tiutiunyk (Doctor of Technical Sciences, Senior Researcher) ${ }^{2}$ \\ Olha Tiutiunyk (Candidate of Technical Sciences, Associate Professor) ${ }^{3}$
}

\author{
${ }^{1}$ Kharkiv National University of Radio Electronics, Kharkov, Ukraine \\ ${ }^{2}$ National University of Civil Protection of Ukraine, Kharkov, Ukraine \\ ${ }^{3}$ Simon Kuznets Kharkiv National University of Economics, Kharkov, Ukraine
}

Creation of an efficient informational and analytical subsystem of prevention management processes and localization consequences of the emergency situations (ES) has been offered. It was made by complex inclusion in the operating Unified State Civil Protection System (USCPS) (from object to government) levels of various functional territorial system elements of monitoring emergency and system components of the situational centers. It was shown that one of trial functions of system situational centers at all USCPS management levels is development of efficient response crisis solutions, which is complicated by the fact that necessary conditions of effectiveness decisions is their timeliness, completeness and optimality. For increase in effectiveness of a decision making need of formal development, normative methods and models of a complex solution of the making decision problem in the conditions of the multicriterial and indeterminacy at prevention management processes and consequences emergency localization has been proved.In order to develop the scientific and technical foundations for creating a support system for making anti-crisis decisions in the system of situational centers of the USCPS, the paper presents a methodology for substantiating optimal anti-crisis solutions to ensure an appropriate level of safety of the state in ES of various nature in conditions uncertainty of input information for experts of the system of situational centers.

Keywords: emergency situation, The Unified State Civil Protection System, the system of the situational centers, support system for making anti-crisis decisions, multi-criteria, uncertainty of initial information. 


\section{References}

1. On National Security of Ukraine: Law of Ukraine of 21 June 2018 № 2469-VIII Available at: http://zakon.rada.gov.ua/laws/show/2469-19 2. Chekhovska M.M. Mizhnarodnyi dosvid stvorennia sytuatsiinykh tsentriv u protsesi bezpekovoho suprovodu realizatsii natsionalnykh interesiv [International experience in creating situational centers in the process of security support of national interests]. Available at: http://pap.in.ua/4_2014/62.pdf 3. Vishnevskij V.V. Organizacionnye procedury situacionnogo centra. / V.V. Vishnevskij, S.V. Simonov // Matematychni mashyny i systemy. 2010. № 4. S. 62-67. Available at: http://nbuv.gov.ua/UJRN/MMS_2010_4 9

Chernogor L.F. (2012). Fizika i jekologija katastrof [Physics and ecology of catastrophes]. Har'kov: Har'kovskij nacional'nyj universitet imeni V.N. Karazina, 2012. 556. 5. Tiutiunyk V.V. Systemnyi pidkhid do otsinky nebezpeky zhyttiediialnosti pry terytorialno chasovomu rozpodili enerhii dzherel nadzvychainykh sytuatsii. / V.V Tiutiunyk, L.F. Chernogor, V.D. Kalygin // Problemy nadzvychainykh sytuatsii. 2011. Vip.14. S.171-194. 6. Order of the Cabinet of Ministers of Ukraine of January 25, 2017 № 61-r. "On approval of the Strategy for reforming the system of the Civil Service of Ukraine for Emergencies". Available at: http://zakon5.rada.gov.ua/laws/show/61-2017-\%D1\%80.

7. Kalygin V.D. Systemnyi pidkhid do otsinky ryzykiv nadzvychainykh sytuatsii v Ukraini. / V.D. Kalygin, V.V Tiutiunyk, L.F. Chernogor, R.I. Shevchenko // Vostochno-Evropejskij zhurnal peredovyh tehnologij. 2012. 1/6 (55). S. 59-70. 8. Tiutiunyk V.V. Osnovy metodolohii terytorialno-chasovoho formuvannia dzherel nadzvychainykh sytuatsii ta ekolohichnoi nebezpeky na lokalnii terytorii. / V.V Tiutiunyk, O.M. Sobol, V.D. Kalygin, Ju.V. Tiutiunyk // Tekhnohenno-ekolohichna bezpeka ta tsyvilnyi zakhyst. Kyiv: Instytut heokhimii navkolyshnoho seredovyshcha NAN Ukrainy. 2015. Vyp.9. S.92-108. 9. Tiutiunyk V.V. (2015). Stvorennia kompleksnoi systemy monitorynhu nadzvychainykh sytuatsii v rehionakh Ukrainy. Avtoref. ... doktora tekhnichnykh nauk za spets. 21.02.03 - Tsyvilnyi zakhyst [Creation of a complex system of emergency monitoring in the regions of Ukraine. Author's ref. ... Doctor of technical sciences for spets. 21.02.03 - Civil Protection]. Kyiv: NAN Ukrainy. DP «Instytut heokhimii navkolyshnoho seredovyshcha NAN Ukrainy», 2015. 42. 10. Tiutiunyk V.V. Rozvytok metodolohichnoho pidkhodu dlia tekhnohennoekolohichnoi otsinky rivnia nebezpeky funktsionuvannia strukturnykh pidrozdiliv potentsiino nebezpechnykh ob'iektiv ta lokalnykh terytorii Ukrainy. I V.V Tiutiunyk, V.M. Strilets, V.D. Kalygin, Ju.V. Zakharchenko // Naukovo-tekhnichnyi zhurnal «TEKhNOHENNO-EKOLOHIChNA BEZPEKA». № 3(1/2018). S. 91-101. 11. Glushkov V.M. (1962). Vvedenie $\mathrm{v}$ teoriju samosovershenstvujushhihsja sistem [Introduction to the theory of self-improving systems]. Kiev: Izd-vo KVIRTU,1962. 109.12. Fishbern P. (1978). Teorija poleznosti dlja prinjatija reshenij [Utility theory for decision making]. M.: Nauka, 1978. 352. 13. Saati T. (1977). Matematicheskie modeli konfliktnyh situacij [Mathematical models of conflict situations]. M.: Sov. Radio, 1977. 304. 14. Kini R.L., Rajfa H. (1981). Prinjatie reshenij pri mnogih kriterijah: predpochtenija i zameshhenija [MultiCriteria Decision Making: Preferences and Substitutions]. M.: «Radio i svjaz'», 1981. 560. 15. Zade L. (1976). Ponjatie lingvisticheskoj peremennoj i ego primenenie $\mathrm{k}$ prinjatiju priblizhennyh reshenij [The concept of a linguistic variable and its application to making approximate decisions]. M.: «Mir», 1976. 16. Podinovskij V.V.,
Nogin V.D. (1982). Pareto-optimal'nye reshenija mnogokriterial'nyh zadach [Pareto-optimal solutions of multicriteria problems]. M.: Nauka, 1982. 254. 17. Zaichenko Yu.P. (2006). Doslidzhennia operatsii [Operations Research]. 7-me vyd. K.: Vydavnychyi Dim «Slovo», 2006. 816. 18. Voloshyn O.F., Mashchenko S.O. (2006). Teoriia pryiniattia rishen: Navchalnyi posibnyk [Decision Theory: A Textbook]. K.: Vydavnychopolihrafichnyi tsentr «Kyivskyi universytet», 2006. 304. 19. Larichev O.I., Moshkovich E.M. (1996). Kolichestvennye metody prinjatija reshenij [Quantitative decision making methods]. M.: Nauka, Fizmatlit, 1996. 208. 20. Borisov A.N., Krumberg O.A., Fedorov I.P. (1990). Prinjatie reshenij na osnove nechetkih modelej: Primery ispol'zovanija [Fuzzy Model Decision Making: Case Studies]. Riga: Zinatne, 1990. 184. 21. Voshhinin A.P., Sotirov G.R. (1989). Optimizacija v uslovijah neopredelennosti [Optimization under uncertainty]. Izd-vo MJeI i Tehnika, 1989. 224. 22. Kofman A. (1982). Vvedenie $\mathrm{v}$ teoriju nechetkih mnozhestv [Introduction to fuzzy set theory]. M., Radio i svjaz', 1982. 23. Orlovskij S.A. (1981). Problemy prinjatija reshenij pri nechetkoj informacii [Decision-making problems with fuzzy information]. M.:Nauka, 1981. 206. 24. Pospelov D.A. (1981). Logiko-lingvisticheskie modeli V sistemah upravlenija [Logical and linguistic models in control systems]. M.: Jenergoizdat, 1981. 232. 25. Rotshtejn A. P. (1999). Intellektual'nye tehnologii identifikacii: nechetkaja logika, geneticheskie algoritmy, nejronnye seti [Intelligent identification technologies: fuzzy logic, genetic algorithms, neural networks]. Vinnica: UNIVERSUM - Vinnica, 1999. 320. 26. Petrov E.G. Analiz podhodov k resheniju zadachi poiska optimal'nogo reshenija $\mathrm{v}$ uslovijah neopredelennosti. / E.G. Petrov O.A. Pysklakova // Vestnik HNTU. 2007. №4(27). S. 14-19. 27. Petrov E.G. Postanovka zadachi vzaimnoj transformacii razlichnyh vidov neopredelennosti. / E.G. Petrov O.A. Pysklakova // Kompiuterne modeliuvannia ta intelektualni systemy: Zbirnyk naukovykh prats. 2007. S. 190-193. 28. Petrov E.G., Novozhylova M.V., Hrebennik I.V. (2004). Metody i zasoby pryiniattia rishen v sotsialno - ekonomichnykh systemakh [Methods and means of decision making in socio - economic systems]. K.: Tekhnika, 2004. 256. 29. Prohorov Ju.V. (1988). Matematicheskij jenciklopedicheskij slovar' [Mathematical encyclopedic dictionary]. M.: Sov. jenciklopedija, 1988. 250. 30. Nejman Dzh., Morgenshtern O. (1970). Teorija igr i jekonomicheskoe povedenie [Game theory and economic behavior]. M.: Nauka, 1970. 124. 31. Ivahnenko A.G, Mjuller J.A. (1985). Samoorganizacija prognozirujushhih modelej [Self-organization of predictive models]. K.:Tehnika, 1985. 223. 32. Kliger S.A., Kosolapov M.S., Tolstova Ju.N. (1978). Shkalirovanie pri sbore $\mathrm{i}$ analize sociologicheskoj informacii [Scaling in the collection and analysis of sociological information]. M.: Nauka, 1978. 168. 33. Katulev A.N., Vilenchuk L.S., Mihno V.N. (1992). Sovremennyj sintez kriteriev v zadachah prinjatija reshenij [Modern synthesis of criteria in decision-making problems]. M.: Radio i svjaz', 1992. 119. 34. Petrov E.G. Metodika ocenki adekvatnosti modelej tochechnoj identifikacii individual'nyh predpochtenij LPR. / E.G. Petrov, N.S. Shilo // Radiojelektronika i informatika. 2003. №2. S. 97-103. 35. Ruban I. Features of decision support by experts of the situational center under conditions of uncertainty of input information in emergency situations. / Igor Ruban, Vadym Tiutiunyk, Olha Tiutiunyk // Informatsiini tekhnolohii $\mathrm{i}$ bezpeka. Materialy XX Mizhnarodnoi naukovo-praktychnoi konferentsii ITB-2020. 2020. S. $120-124$. 